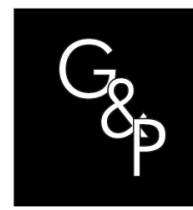

\title{
An analysis of the relationship between knowledge management and project performance: literature review and conceptual framework
}

\author{
Uma análise da relação entre gestão do conhecimento e \\ desempenho do projeto: revisão da literatura e quadro conceitual \\ Camila Favoretto $^{1}$ (), Marly Monteiro de Carvalho ${ }^{2}$ (]) \\ ${ }_{1}^{1}$ Departamento de Engenharia de Produção, Universidade Federal de São Carlos - UFSCar. São Carlos, SP, Brasil. E-mail: \\ cam.favoretto@gmail.com \\ ${ }^{2}$ Escola Politécnica, Universidade de São Paulo - USP, São Paulo, SP, Brasil. E-mail: marlymc@usp.br
}

How to cite: Favoretto, C., Carvalho, M. M. (2021). An analysis of the relationship between knowledge management and project performance: literature review and conceptual framework. Gestão \& Produção, 28(1), e4888. http://dx.doi.org/10.1590/0104-530X4888-20

\begin{abstract}
Knowledge management is a key resource for enabling projects and organizations to address the current challenges of competitive environment. This article aims to investigate the central themes of knowledge management in the project context, exploring the relationship between knowledge management and project performance. For this purpose, a literature review was carried out, adopting bibliometric analysis, codification and content analysis. The search and sampling process was conducted in the Web of Knowledge (Web of Science Core Collection) database. First, the results identified the main strategies to deal with tacit and explicit knowledge, which are experts' knowledge acquisition and project documentation through coded forms, respectively. Both types of knowledge, tacit and explicit, are strongly related to two of the project success dimensions: GP efficiency, and success of the product/service. The literature pointed out that organizations recognize the importance of knowledge management but they still face many barriers to implement it in practice. The publications allowed verifying that the subjects are still little related, making it a challenging field for future studies.
\end{abstract}

Keywords: Project management; Knowledge management; Performance.

Resumo: O gerenciamento do conhecimento é um dos principais recursos a permitir que projetos e organizações lidem com os desafios do mercado competitivo atual. Esse estudo tem como objetivo investigar os temas centrais da gestão de conhecimento no contexto de projeto, explorando a relação entre gestão de conhecimento e o desempenho de projetos. Para tal, foi realizada uma revisão de literatura, adotando análise bibliométrica, codificação e análise de conteúdo. O processo de busca e amostragem foi conduzido na base de dados da Web of Knowledge (Web of Science Core Collection). Os resultados identificaram as principais estratégias para lidar com que os conhecimentos tácito e explícito, que são aquisição de conhecimentos de especialista e documentação do projeto por meio de formulários codificados, respectivamente. Ambos os tipos de conhecimento, tácito e explicito, estão mais intensamente relacionados a duas dimensões de sucesso: eficiência na GP e sucesso do produto / serviço. A literatura aponta que muitas organizações reconhecerem a importância da gestão do conhecimento, mas ainda são muitas as barreiras para sua implementação na prática.

Palavras-chave: Gestão de projetos; Gestão do conhecimento; Desempenho.

Received em Jun. 1, 2018 - Accepted em Set. 14, 2018

Financial support: The authors acknowledge CNPq and CAPES for support. 


\section{Introduction}

The complex and unpredictable nature of projects poses serious challenges to project managers and project-based organizations (Landaeta, 2008). Knowledge is one of the key resources that enable projects and organizations to address these challenges. In the effort to adapt and to develop new knowledge, companies have several options for developing internal knowledge, such as interpersonal knowledge networks, and a wide range of external knowledge delivery strategies, including alliances and acquisitions (Grigoriou \& Rothaermel, 2017).

In this scenario, knowledge is treated as a critical driving force to achieve the company's performance goals. This is because knowledge facilitates the best business decision-making processes in a timely manner (Han \& Park, 2009). For Duffield \& Whitty (2016), a company cannot manage project risks without managing its knowledge; projects thus fail due to lack of lessons learned or lack of knowledge sharing.

Cohen \& Olsen (2015) argue that, while not always explicitly recognized, the theoretical perspectives on the relationship between knowledge management (KM) and its implications for performance have supported previous research, such as that of Andreeva \& Kianto (2012), Storey \& Hull (2010) and Choi \& Lee (2003). From a practical point of view, companies realized the importance of managing knowledge to stay competitive. However, many knowledge management systems were not successful. Therefore, a divergence in the practitioner's view on knowledge management and the academic perspective is already evident (López-Nicolás \& Meroño-Cerdán, 2011).

However, despite the importance of knowledge management in projects, the reference guides give little attention to the topic. Only in its 6th edition (PMI, 2017) did the Project Management Body of Knowledge include a process related to Knowledge Management.

To fill this gap, this study aims to investigate the central themes of knowledge management in the context of the project, exploring the relationship between knowledge management and project performance. For this, the methodological approach adopted was a systematic review of the literature, using bibliometric techniques and content analysis, with a sample of articles from the Web of Knowledge (Web of Science Core Collection) database. In the process of content analysis, a coding system was developed that guided the analysis of the networks and the relationships between the central themes of the research. The objective was detailed in the following research questions: (QP1) What are the central themes of knowledge management in projects? (QP2) What is the relationship between knowledge management and project performance?

The study contributes to the literature by providing an overview of the concepts project management, knowledge management and performance, highlighting aspects relevant to these subjects in the academic literature. In addition, it promotes a better understanding of the relationship between concepts, which allows identifying their impacts.

The rest of the paper is structured as follows: section 2 presents the theoretical reference, which deals with the researched concepts; section 3 shows the methodology used, which involves the process of data sampling and analysis, through bibliometric analysis, coding and content; section 4 contains the presentation of the results; section 5 the discussion of the results yielded; and finally, section 6 demonstrates the conclusions, limitations, and future research. 


\section{Literature review}

\subsection{Knowledge management}

Despite the broad range of research on knowledge management, there seems to be no universal definition of the term, just as there is no consensus on what constitutes it. For (Suresh et al., 2016), the various definitions of knowledge can be summarized and classified into: definitions of the classical era of knowledge, as a justified true belief and contemporary definitions of knowledge, as a mixture of experiences, values and information. Contemporary definitions are more relevant to management as they focus on the use of knowledge and the notion of knowledge as a practical tool for framing experiences, sharing ideas, and assisting with practical tasks. Therefore, knowledge management implies understanding the uses of knowledge to effectively deal with the practical tasks involving knowledge-based activities.

The literature recognizes as a dominant aspect of knowledge management the conversion of knowledge through the interfaces between tacit and explicit knowledge (Nonaka \& Takeuchi, 1995; Reich et al., 2012). Explicit knowledge is usually formal and systematic and can be shared easily, since the tacit is personal and difficult to formalize and may be difficult to capture or communicate with others (Nonaka \& Takeuchi, 1995). The conversion of knowledge is made up of four interfaces known as SECl: socialization (tacit knowledge conversion into tacit knowledge), externalization (tacit to explicit), combination (explicit to explicit) and internalization (explicit to tacit). Thus, knowledge management involves all the practices of an organization to create, store, use and share knowledge (Lindner \& Wald, 2011).

Within this perspective, in projects, one of the main questions for knowledge management is the poor analysis of the project success and the lack of adequate documentation on the results of previous projects (Todorović et al., 2015). This difficulty may be associated with the temporality of the projects, which causes knowledge sharing to require external effort (Duffield \& Whitty, 2016). This effort can bring a substantial/sound investment to the organization, whereby the financial gains from the effective management of the project knowledge is difficult to measure. Another difficulty arises from the observation that the implementation of knowledge management in the project configurations still seems to be insufficiently used. This general deficiency in business practice is impressive in terms of the high potential benefits in terms of efficiency, effectiveness and innovation resulting from project knowledge management successfully implemented in different types of companies (Hanisch et al., 2009).

Tacit knowledge, as individual experiences, is a primary source of project management competence. Not opposing the benefits of $\mathrm{KM}$, identifying critical knowledge and reusability remains a challenge for many project organizations (Yap et al., 2017).

According to Landaeta (2008), projects need three types of knowledge to achieve their goals. The first, technical knowledge, allows projects to perform their tasks as prescribed. However, when problems arise, a different kind of knowledge is needed, knowledge to solve them. The third type of knowledge allows continuous improvement of project tasks. For Zhang et al. (2017), standardization, knowledge management through lessons learned, and cost management for budget control using information systems are necessary for project management. 


\subsection{Performance in projects}

Project performance has been the subject of discussions in the project management literature. According to Carvalho et al. (2015), the traditional view of project success is associated with the achievement of time, cost and quality objectives (iron triangle). However, several studies have investigated new dimensions of project success (Carvalho \& Rabechini, 2015). Thus, there seems to be no simple definition for this construction, since it can be measured differently in different types of projects, from different perspectives, at different stages and in absolute or relative terms, which makes it a multidimensional construct (Carvalho et al. al., 2015).

Thus, studies analyze their relation to other constructs. For Carvalho \& Rabechini (2015), although some studies have found that risk management has a low impact on project performance, others have suggested that even moderate levels of risk management planning are sufficient to reduce the negative effects of risk on project success. These distinct findings can be explained by the contingency approach, in which the type of project can affect not only a project performance but also the effectiveness of project management practices. Another explanation for the contradictory findings is that these studies focus on risk management, neglecting relevant aspects of uncertainty management, such as the soft skills of project stakeholders, represented by behavioral competencies that include skills such as negotiation, leadership, conflict management, among others.

Carvalho \& Rabechini (2017) point out a lack of confirmatory studies about the relationship between sustainability and project performance, which are thus sought in this study. The results reinforce the perspective of a positive and significant impact among the constructs. Failing to identify a negative influence on project performance if related to costs.

\subsection{Knowledge management and performance in projects}

The relationship of knowledge management and project performance still represent a research gap (Cohen \& Olsen, 2015). Previous studies provide empirical evidence of a positive impact between these constructs (Reich et al., 2014; Lindhard \& Larsen, 2016). However, the mechanisms of this relationship are not fully understood, as there is still a limitation in understanding how systems can be aligned with organizational goals and strategies (Ali et al., 2018).

In their search for this understanding, Lindhard \& Larsen (2016) present knowledge sharing and communication as key to improving cost, time and quality performance. Thus, a better sharing of experiences and communication will increase the likelihood of the project success through improved skills, commitment and coordination. Cunha et al. (2014) corroborate that knowledge management is an important integrative function, with impacts organizational learning and, consequently, project performance.

\section{Research methods}

To achieve our aim to investigate the relationship between project management and knowledge management in a performance context, we decided to carry out a systematic review of the literature. There are different possibilities that can be 
considered in the development of a literature review; a combination of bibliometric and content analysis was used herein. These analyses are complementary, since the first attempts to identify literature patterns based on publication data, and the second capture information to quantify word sequences to model a related language used by different research fields (Carvalho et al., 2013). The flow chart of the literature review is shown in Figure 1.

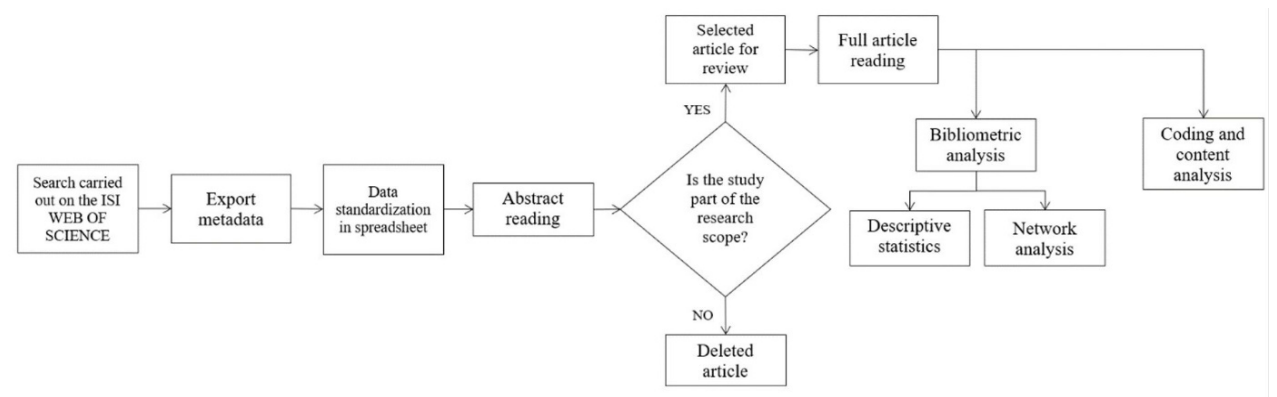

Figure 1. Flow chart of the systematic literature review.

Source: Prepared by the authors.

\subsection{Sampling procedure}

To obtain the initial sample, the ISI Web of Science Core Collection database was selected, as it provides an interface for simultaneously searching documents in other databases and is also the source for calculating the Journal Citation Report (JCR) index, one of the mechanisms most used to evaluate journals based on citation data (Franco et al., 2018). The research was carried out using the following search filter: "project management" AND "knowledge management" AND (performance OR success). Only publications of the type "articles" were selected, due to the rigor of their publication; no temporal or area filters were used. As a result, it was possible to identify 84 articles.

After the sample definition, we proceeded with the export of the metadata of these studies to a spreadsheet. The next step consisted in organization and standardization of the data collected. Subsequently, the abstracts of the 84 articles were analyzed to verify their alignment with the researched topic, 47 were excluded, as they were not within the scope of this study, resulting in 37 articles selected for analysis.

\subsection{Data analysis}

The data analysis was based on bibliometrics and content analysis. Bibliometric analysis aimed at verifying aspects such as: evolution of the number of publications and citations over time, periodicals of greater relevance, in addition to the authors' co-citation networks and co-citation of the references. The descriptive statistics analyses were elaborated with the help of Excel and the networks with the help of VOSVIEWER software.

Finally, content analysis was performed by means of a careful reading of the articles. A coding scheme was developed to classify the works according to the codes presented in Table 1. After the content analysis, the analysis of relationships between codes and core-periphery were elaborated with the aid of UCINET 6 (Borgatti et al., 2002). 
Table 1. Stratification of Codes.

\begin{tabular}{|c|c|}
\hline $\begin{array}{l}\text { C1 - Type of study } \\
\text { Franco et al. (2018) }\end{array}$ & $\begin{array}{l}\text { C5 - Knowledge } \\
\text { Nonaka \& Takeuchi (1995) }\end{array}$ \\
\hline TE1 - Modeling & C1 - Tacit \\
\hline TE2 - Theoretical-conceptual & C2 - Explicit \\
\hline \multicolumn{2}{|l|}{ TE3 - Survey } \\
\hline TE4 - Literature review & C6 - Explicit-oriented indicators \\
\hline TE5 - Simulation & Choi \& Lee (2003) \\
\hline TE6 - Case study & IE1 - Knowledge coding \\
\hline TE7 - Action research & IE2 - Acquiring knowledge of codified forms \\
\hline \multirow[t]{2}{*}{ TE8 - Experimental } & IE3 - Documentation \\
\hline & IE4 - Sharing knowledge through coded forms \\
\hline \multicolumn{2}{|l|}{$\begin{array}{l}\text { C2 - Approach } \\
\text { Franco et al. (2018) }\end{array}$} \\
\hline A1 - Qualitative & $\begin{array}{l}\text { C7 - Tacit-oriented indicators } \\
\text { Choi \& Lee (2003) }\end{array}$ \\
\hline A2 - Quantitative & IT1 - Acquiring knowledge from specialists and co-workers \\
\hline \multirow[t]{2}{*}{ A3 - Multi-method } & IT2 - Face-to-face help by experts \\
\hline & IT3 - Informal dialogues for knowledge sharing \\
\hline C3- Level of analysis & IT4 - Acquisition of knowledge by individual guidance \\
\hline \multicolumn{2}{|l|}{ NA1 - Individual } \\
\hline NA2 - Project & $\begin{array}{l}\text { C8 - Dimensions of project performance } \\
\text { Carvalho \& Rabechini (2015) }\end{array}$ \\
\hline \multirow[t]{2}{*}{ NA3 - Organizational } & DDP1 - Product / service \\
\hline & DDP2 - GP efficiency \\
\hline \multirow{2}{*}{$\begin{array}{l}\text { C4 - Sector } \\
\text { Choi \& Lee (2003) }\end{array}$} & DDP3 - Impact on team \\
\hline & DDP4 - Present impact on business \\
\hline S1 - Manufacturing & DDP5 - Future impact on business \\
\hline S2 - Service & DDP6 - Impact on the customer \\
\hline S3 - Financial & DDP7 - Social and environmental impact \\
\hline S4 - Others & \\
\hline
\end{tabular}

Source: Adapted from the articles presented in the table.

\section{Presentation and discussion of results}

\subsection{Analysis of publications}

The analysis of publications aims to verify trends of growth or reduction of interest in relation to the subject studied. The temporal evolution of the publications and citations can be observed in Graph 1. The solid line represents the evolution of the publications and the dashed line, of the citations. As verified, the number of publications began in 1999; however, between 2000 and 2005, no studies on the subject were found. From 2006 to date, there is an average of 3 articles per year, showing a stability in relation to the interest in the subject. However, due to the number of publications, the themes of project management, knowledge management and performance can be observed to be still poorly related. As far as citations are concerned, a significant increase has been observed since 2008, reaching a level of 134 citations in 2016 and a total of 663 over the period, 
demonstrating that the researchers are interested in the subject and that they use the publications selected by this study as the main references.

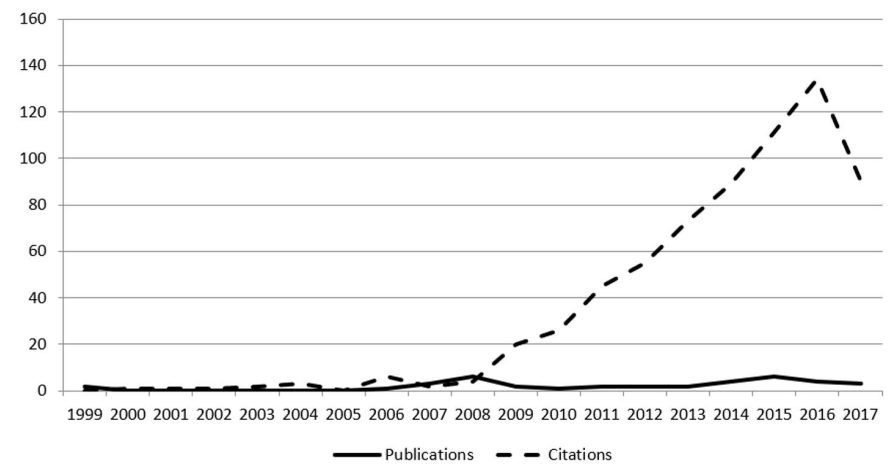

Graph 1. Time evolution of publications and citations. Source: Prepared by the authors.

Another analysis performed in this study meant to identify articles with the highest number of citations. Table 2 identifies the eight main articles on the subject studied, with a total of 358 citations, representing approximately $53 \%$ of the sample citations. The table also indicates that the articles were publications between 2007 and 2014. The first most cited article is Lindner \& Wald (2011) with 75 citations. In the study, they seek to detect the success factors in knowledge management in project temporary organizations.

Table 2. Most cited articles.

\begin{tabular}{|c|c|c|c|}
\hline Title & Authors & Year & Citations \\
\hline $\begin{array}{l}\text { Success factors of knowledge management in } \\
\text { temporary organizations }\end{array}$ & Lindner, F.; Wald, A. & 2011 & 75 \\
\hline $\begin{array}{l}\text { Critical factors for knowledge management in } \\
\text { project business }\end{array}$ & Ajmal, M; Helo, P; Kekale, T. & 2010 & 55 \\
\hline $\begin{array}{l}\text { Systems development process improvement: A } \\
\text { knowledge integration perspective }\end{array}$ & Patnayakuni, R.; Rai, A.; Tiwana, A. & 2007 & 43 \\
\hline Knowledge management in project environments & $\begin{array}{l}\text { Hanisch, B; Lindner, F; Mueller, A; } \\
\text { Wald, A. }\end{array}$ & 2009 & 40 \\
\hline $\begin{array}{l}\text { Knowledge sharing in information systems } \\
\text { development projects: Explicating the role of } \\
\text { dependence and trust }\end{array}$ & Park, J.; Lee, J. & 2014 & 38 \\
\hline $\begin{array}{l}\text { Post-project reviews as a key project management } \\
\text { competence }\end{array}$ & $\begin{array}{l}\text { Anbari, F. T.; Carayannis, E. G.; } \\
\text { Voetsch, R. J. }\end{array}$ & 2008 & 37 \\
\hline $\begin{array}{l}\text { Process-centered knowledge model and } \\
\text { enterprise ontology for the development of } \\
\text { knowledge management system }\end{array}$ & Han, K. H.; Park, J. W. & 2009 & 35 \\
\hline $\begin{array}{l}\text { Evaluating benefits and challenges of knowledge } \\
\text { transfer across projects }\end{array}$ & Landaeta, R. E. & 2008 & 35 \\
\hline $\begin{array}{l}\text { New product development team intelligence: } \\
\text { Antecedents and consequences }\end{array}$ & $\begin{array}{l}\text { Akgun, Ali E.; Dayan, Mumin; Di } \\
\text { Benedetto, Anthony }\end{array}$ & 2008 & 32 \\
\hline
\end{tabular}

Source: Prepared by the author

The articles collected had their publications distributed in 23 journals. Table 3 presents the most relevant journals, which had at least two publications on the subject and together accumulate $21(55 \%)$ of the 38 publications. Note the importance of the International 
Journal of Project Management, the periodical with the greatest impact factor among the journals selected, containing eight publications, which encourages researchers to use it.

It is also possible to observe that although the relationship between the subjects studied is recent, several journals have published articles related to the subject, evidencing that the theme is not concentrated in journals in the research area of project management and knowledge management, but also in journals of information technology (Information \& Management and Expert Systems with Applications), innovation (Technovation) and engineering (Proceedings of the Institution of Civil Engineers).

Table 3. Relevant journals.

\begin{tabular}{lcc}
\hline \multicolumn{1}{c}{ Journal } & Publications & Impact factor \\
\hline International Journal of Project Management & 8 & 4,2 \\
\hline Journal of Knowledge Management & 5 & 2,0 \\
\hline Expert Systems with Applications & 2 & 3,9 \\
\hline Information \& Management & 2 & 3,3 \\
\hline Technovation & 2 & 3,3 \\
\hline Proceedings of the Institution of Civil Engineers-Management & 2 & - \\
Procurement and Law & 2 & \\
\hline
\end{tabular}

Source: Prepared by the authors.

In relation to the authors most relevant to the theme of this study, a dispersion was verified, since 89 authors were identified, only 10 of them with two publications, which demonstrates the absence of a concentration of reference authors in the project management, knowledge management and performance study fields. The authors of the paper "Knowledge Management in Project Environments" written in a partnership with Bastian Hanisch and Ana Mueller and "Success factors of knowledge management in temporary organizations" are among the eight most cited articles of the sample, with 40 and 75 citations, respectively, and were published in relevant journals - Journal of Knowledge Management and International Journal of Project Management respectively-, proving the importance of these two authors for this theme. The first article points out the success of knowledge management in projects being determined mainly by cultural factors, while technical aspects such as information systems and project management methods are only considered support factors. In order to corroborate this result, the second article aims to test the influence of cultural, organizational, structural and processrelated factors on the effectiveness of knowledge management. As a result, they show that besides IT support, formal elements of the organization strongly influence the success of knowledge management. They affirmed that in temporary organizations, they compensate for the lack of organizational routines and organizational memory.

\subsection{Central authors and references}

The first analysis is about the authors' co-citation network, verified how the authors mentioned by the 37 articles of the sample relate, enabling the formation of clusters. In this case, clusters represent groups of authors that are quoted together more frequently, and can thus determine a major theme researched. Figure 2 shows the network of citations found with the help of software VOSVIEWER. The criterion for forming the network was authors with at least four citations, which totaled 10 authors out of the 57 authors of the sample, most containing 0 citations. 


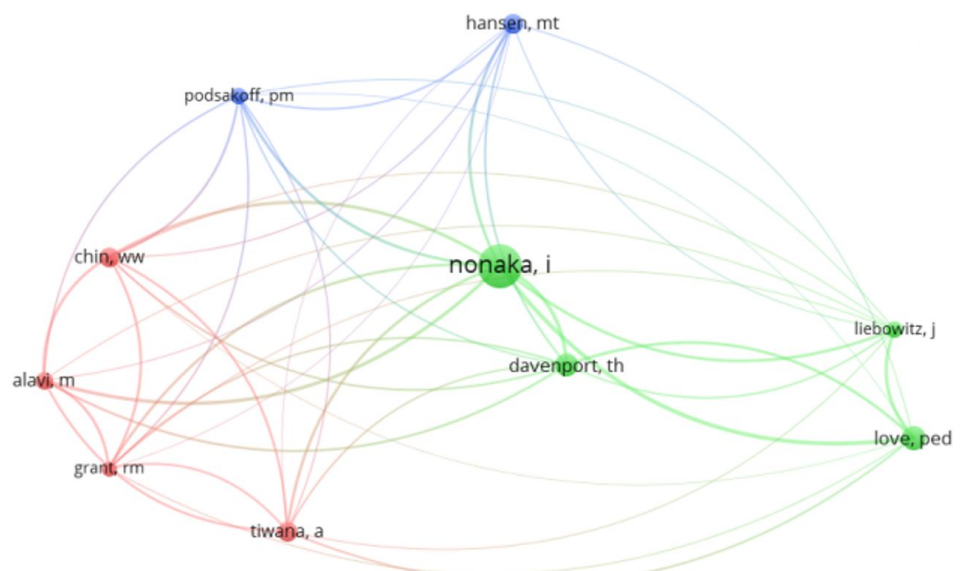

Figure 2. Authors' co-citation network.

Source: Prepared by authors from VOSVIEWER.

From this network, illustrated in Figure 2, it was possible to identify three clusters: the first one (green color), with four representatives, led by Ikujiro Nonaka, one of the greatest references in the literature on knowledge management; the second cluster (red color) groups authors such as Wynne W. Chin, author of works on the modeling technique of structural equations and Amrit Tiwana, researcher on knowledge management and information systems. Finally, the third cluster (blue color), has only two representatives Morten T. Hansen, reference author on networks of knowledge in projects and Philip M. Podsakoff recognized by works in the methodological area regarding the construction of indicators and measurement model in the marketing and consumer research fields.

The second analysis refers to the network of reference citations, shown in Figure 3. This network represents the 10 main references that appear in the articles of the sample and had as its criterion of choice; out of the 1774 references, those that presented a minimum number of three citations. As a highlight, it is possible to observe the greatest relevance for Nonaka \& Takeuchi (1995) entitled "The knowledge-creating company: How Japanese companies create the dynamics of innovation" with 16 citations. This implication, supported by the results found in the network of authors, confirms the importance of the research by Ikujiro Nonaka for the researched subject.

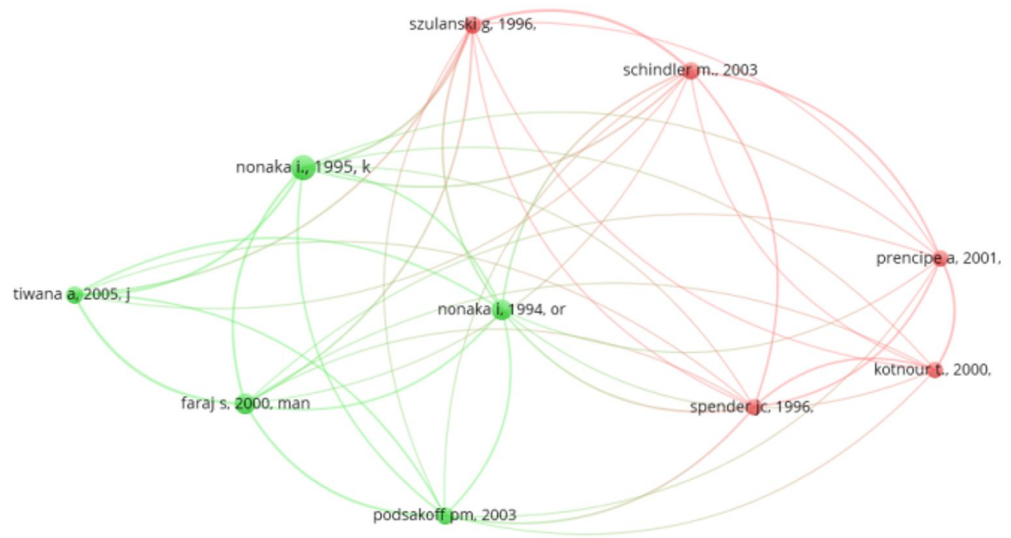

Figure 3. Network of reference cocitation. Source: Prepared by authors with VOSVIEWER. 


\subsection{Content analysis}

Content analysis was applied with the purpose of answering the research question of this study: (QP1) What are the central themes of knowledge management in projects?

\subsubsection{Descriptive analysis of the coding scheme}

Table 4 shows a summary of the coding result of the 37 articles in the sample using the coding scheme already shown in Table 1 . The complete result of the content analysis of each article is available in Appendix A. The cross-analysis of the data according to the coding scheme is presented in Appendix B.

Table 4. Coding of selected articles.

\begin{tabular}{|c|c|c|c|c|c|}
\hline C1 - Type of study & Articles & $\%$ & C5 - Knowledge & Articles & $\%$ \\
\hline TE1 - Modeling & 3 & 8 & C1 - Tacit & 28 & 76 \\
\hline TE2 - Theoretical-conceptual & 6 & 16 & C2-Explicit & 25 & 68 \\
\hline TE3 - Survey & 22 & 54 & & & \\
\hline TE4 - Literature review & 1 & 3 & C6 - Explicit-oriented indicators & Articles & $\%$ \\
\hline TE5 - Simulation & 0 & 0 & IE1 - Knowledge coding & 9 & 24 \\
\hline TE6 - Case study & 5 & 14 & IE2 - Acquiring knowledge of codified forms & 4 & 11 \\
\hline TE7 - Action research & 2 & 5 & IE3 - Documentation & 15 & 41 \\
\hline TE8 - Experimental & 0 & 0 & IE4 - Sharing knowledge through coded forms & 6 & 16 \\
\hline C2-Approach & Articles & $\%$ & C7 - Tacit-oriented indicators & Articles & $\%$ \\
\hline A1 - Qualitative & 13 & 35 & $\begin{array}{l}\text { IT1 - Acquiring knowledge from specialists and } \\
\text { co-workers }\end{array}$ & 17 & 46 \\
\hline A2 - Quantitative & 20 & 54 & IT2 - Face-to-face help by experts & 2 & 5 \\
\hline \multirow[t]{2}{*}{ A3 - Multi-method } & 3 & 8 & IT3 - Informal dialogues for knowledge sharing & 13 & 35 \\
\hline & & & $\begin{array}{l}\text { IT4 - Acquisition of knowledge by individual } \\
\text { guidance }\end{array}$ & 5 & 14 \\
\hline C3 - Level of analysis & Articles & $\%$ & & & \\
\hline NA1 - Individual & 6 & 16 & C8 - Dimensions of project performance & Articles & $\%$ \\
\hline NA2 - Project & 25 & 68 & DDP1 - Product / service & 17 & 46 \\
\hline \multirow[t]{2}{*}{ NA3 - Organizational } & 18 & 49 & DDP2 - GP efficiency & 21 & 57 \\
\hline & & & DDP3 - Impact on team & 9 & 24 \\
\hline C4 - Sector & Articles & $\%$ & DDP4 - Present impact on business & 10 & 27 \\
\hline S1 - Manufacturing & 8 & 22 & DDP5 - Future impact on business & 4 & 11 \\
\hline S2 - Service & 16 & 43 & DDP6 - Impact on the customer & 0 & 0 \\
\hline S3 - Financial & 0 & 0 & DDP7 - Social and environmental impact & 1 & 3 \\
\hline S4 - Others & 19 & 51 & & & \\
\hline
\end{tabular}

Source: Prepared by the authors

Table 4 allows verifying that the great majority of the articles is linked to the survey methodology with quantitative approach. These two findings show that the interest is in ascertaining the opinions, characteristics and attitudes of those involved by means of a research instrument, obtaining reliable results, which can even be projected for the universe studied for being based on a statistical sample. This is possible, therefore, once there already is a knowledge about the topics covered.

The level of analysis of the articles was in relation to the projects and organization, having little relevance to works concerned with the individual aspect. Of these articles, most do not 
specify the sector of the study or the analysis is carried out in several sectors together, evidencing that the objective concern the project or organization in general and not a specific sector.

The focus of the articles is balanced between tacit and explicit knowledge. With regard to explicit knowledge, documentation is the indicator most cited by researchers as a way of sharing systemic knowledge. According to Todorović et al. (2015), the analysis of the correlation between how knowledge is acquired and transferred and the benefits this generates for project managers and team members, shows that documentation of previously acquired knowledge contributes to more efficient scheduling, resolution reduction of resource consumption, faster execution of tasks. This confirms that several benefits are derived from implementing the proposed concept for knowledge acquisition and transfer. For tacit knowledge, the indicators "acquisition of knowledge from specialists and co-workers" and "informal dialogues for knowledge sharing" are the most representative mechanisms. In addition, the success dimensions of the articles are mainly linked to the efficiency of the project management and the product / service. It is noted that the impact on the client, as well as the social and environmental impact are still little explored by studies.

\subsubsection{Content analysis of sample texts}

The texts of the research sample, detailed in Appendix A, present a very varied theme, whose synthesis of content analysis is discussed in this section.

The studies by Zhang et al. (2017) show that two knowledge issues arise when it comes to growth management. The first question concerns whether an organization has the necessary knowledge resources to enable growth and the second issue is the need for management to have relevant and real-time information to make decisions.

For Suresh et al. (2016), the implementation of knowledge management strategies in construction projects can accumulate benefits such as better performance and continuous improvement. However, many projects still do not use knowledge management completely and are therefore plagued with inefficiencies, repetition of errors, and lack of lessons learned, thus contributing to additional project costs. Lack of skills, design changes, errors and omissions contribute to the internal cost element of failure of the overall cost of poor quality in construction projects. In this same context, Olayinka et al. (2015) concluded that knowledge management has a positive impact but has not been optimized to reduce costs of poor quality due to barriers, such as lack of performance metrics, time constraints and budget. KM optimization to reduce the cost of poor quality was therefore associated with overcoming these barriers: (1) developing performance metrics to assess KM impact on cost, (2) naming and supporting knowledge champions to facilitate $\mathrm{KM}$ activities to reduce cost, (3) encourage organizational culture in relation to KM, (4) allocate time and budget for KM activities, and (5) select acquisition strategies that support KM.

Ajmal et al. (2010) also discuss the barriers to success in knowledge management initiatives and find that the lack of incentives for employees who participated in KM initiatives was the most significant barrier, suggesting that the top management should provide adequate incentive schemes for employees to get involved. The second most significant barrier was the lack of an adequate system to deal with knowledge in projectbased organizations. The lack of coordination between officials and departments was the third most significant barrier, while the lack of familiarity was the fourth most significant. It seems that proper coordination among employees familiar with $\mathrm{KM}$ goals and methods would increase the likelihood of success in KM initiatives. The lack of cultural support was only the fifth most significant barrier identified. Finally, the lack of authority to carry out knowledge activities was the least significant barrier.

The results of Oun et al. (2016) indicate that there is a significant relationship between the four pillars of KM (leadership, organization, technology and learning) and project 
management knowledge areas. Specifically, it shows that project human resource management and project stakeholder management have the strongest association with enterprise-wide KM. Another relationship was studied by Nkuruziza et al. (2016) that concluded that knowledge management and stakeholder involvement are significant predictors of project performance in the agricultural sector. The project team, model farmers, and other agricultural project stakeholders should be equipped with tacit and explicit knowledge and involved in the decision-making process for project success.

For R\&D projects, authors Chandrasekaran \& Linderman (2015) show that projects benefit from two types of knowledge - objective and intuitive. The creation of intuitive and objective knowledge in high-tech organizations occurs by creating not only diverse, but also psychological project teams. The diversity of the team positively influences the objective creation of knowledge, while psychological security affects the creation of intuitive knowledge. Surprisingly, the results show that team diversity negatively affects the intuitive creation of knowledge. A post hoc analysis takes a more detailed look at diversity and shows that different types of diversity have different effects on knowledge creation. The analysis also shows that objective and intuitive knowledge influences the performance of the R\&D project.

The results of the research for Todorović et al. (2015) confirmed that the analysis of project success, presented through the definition of critical success factors, key performance indicators and performance measurement process, has a positive influence on the acquisition of knowledge and transfer in a project environment. That is, if a systematic approach is used when analyzing project success, one can contribute to overcoming one of the main problems in knowledge management in the project environment - the lack of adequate documentation of the results of previous projects. However, we cannot ignore the role of tacit knowledge and the smooth management of components by managing knowledge in the project environment. As for example, the knowledge acquired during the sales phase is an intangible, implicit or even tacit knowledge. This knowledge is difficult to transfer, and since individuals are important repositories of knowledge, it is not possible to transfer all the knowledge gained to another person by simply handing over documents. Instead, deliberate cognitive learning significantly promotes knowledge transfer, and learning about the customer has a positive impact on the cost control of suppliers. Therefore, both written documents and embedded knowledge in individuals involved during the sales phase are necessary for successfully implementing projects (Savolainen \& Ahonen, 2015).

At an individual level, the study by Lee et al. (2014) confirms that leadership increases the level of knowledge sharing among team members, increases the team absorption capacity and leads to better project team performance. Team-level knowledge sharing has the direct effect of improving project performance by providing information and knowledge about the related project, but, on the other hand, it helps to strengthen the path of associating absorptive capacity with project performance.

Using other constructs, Park \& Lee (2014) admit that dependency and trust have a strong impact on knowledge sharing, leading to good project team performance. Findings indicate that team members share their expertise when they trust their partners and when they feel dependent. The feelings of dependence and trust are influenced by the frequency of communication, perceived similarity of the value of the project and the perceived knowledge.

In another perspective, Lindner \& Wald (2011) show that the culture of knowledge is by far the most important success factor. However, not only "soft" factors, such as top management culture and commitment, are essential for a successful transfer of knowledge between and among temporary organizations. They must be complemented by information systems that effectively support communication and storage and retrieval of knowledge in a temporary design environment. It is not the mere availability of systems, but its quality and usefulness are essential. In short, it is the interaction of several factors that lead to a successful transfer of knowledge within and between projects and from the temporary organization to the permanent organization. These authors argue that the effectiveness of knowledge management depends on a set of project management 
practices and dedicated activities that may be related to the extra effort in the project work. It can be assumed that there is a positive relationship between the effectiveness of the management of knowledge and the success of projects.

Proving this, Anbari et al. (2008) point out that the regular collection of lessons learned from projects, their careful storage in the organization's historical information database, and their significant use in subsequent projects are critical elements of project success and organizational competitiveness. This database is an essential resource from which future project teams can begin to build a comprehensive project plan that addresses all areas of project management knowledge. The project history and the lessons learned database provides project managers with the information they need on specific needs for team skills, recruitment-specific employees, customer profiles, and the operating environment that can significantly impact the ultimate success or failure of the project. Historical information and lessons learned can be extremely useful to the project team in various phases of the project lifecycle.

\section{Discussion: Cross-analysis of codes}

To deepen the discussion of research questions, (QP1) What are the central themes of knowledge management in projects? and (QP2) What is the relationship between knowledge management and project performance? cross-analysis of codes were carried out.

QP1 can be answered through the data consolidated in core-periphery analysis of the sample articles, based on the codes of the generated schema. The core-periphery analysis corroborates the importance of the most frequent themes in Table 4, which are both types of knowledge (C1 and C2), the success dimensions of GP Efficiency (DDP1), and product / service success of the project (DDP2), Project Documentation (IE3), Knowledge sharing through coded forms (IT1), in the Service (S2) and Others (S4) sectors. However, the analysis goes further to show that these themes are strongly related in the literature with a core-periphery fit of 0.8852 , as highlighted in Figure 4, between the central themes.

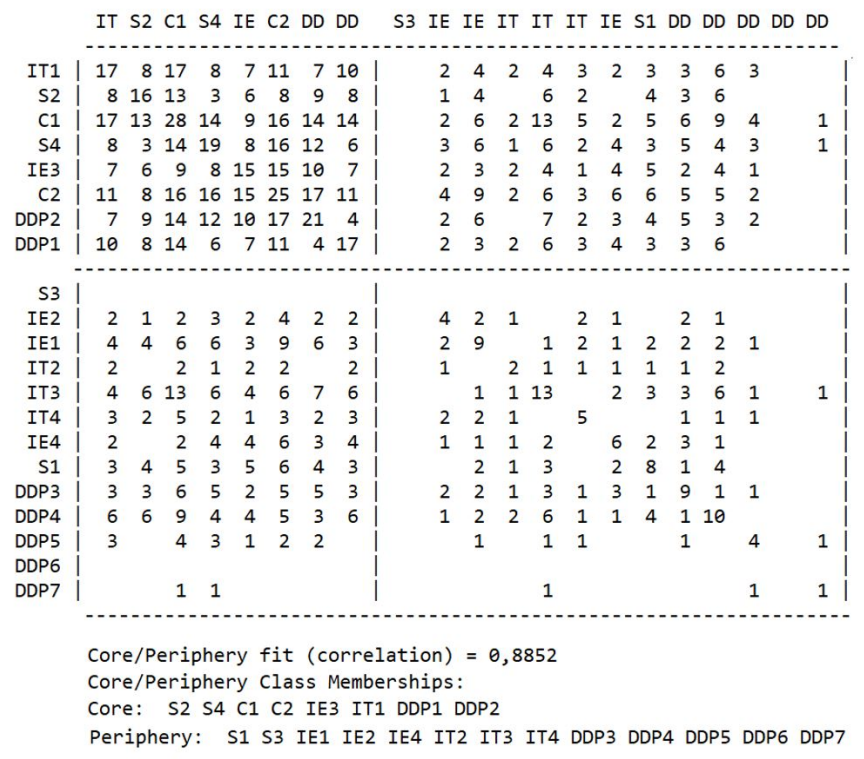

Figure 4. Core-periphery analysis of themes.

Source: Prepared by the authors the UCINET 6 
Regarding QP2, cross-data analysis (see Appendix B) revealed the relationships between key knowledge management themes and project performance, giving insights to the conceptual framework of Figure 5.

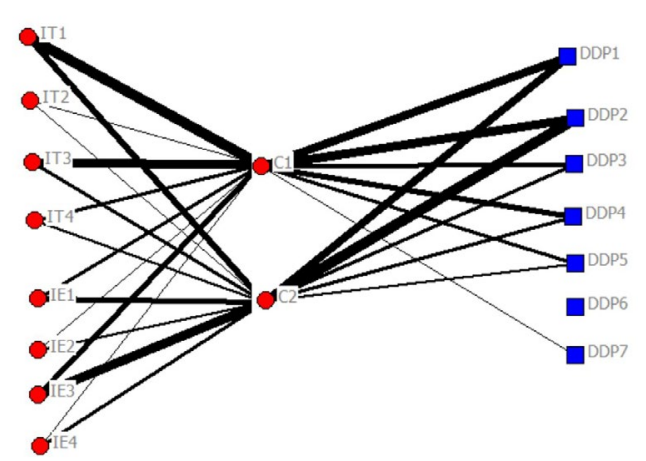

Figure 5. Network of reference co-citation.

Source: Prepared by the authors of the UCINET 6.

It is possible to observe in Figure 4 that, except for the DDP6 dimension, the others have connections with both tacit (C1) and explicit knowledge (C2).

\section{Conclusions}

This article contributes to the literature in two ways. First, the results identified the main strategies to deal with tacit and explicit knowledge, which are experts' knowledge acquisition and project documentation through coded forms, respectively. Both types of knowledge, tacit and explicit, are strongly related to two of the project success dimensions: GP efficiency and success of the product/service. Second, it was possible to establish the relationship between the variables of the coding system to propose a conceptual framework to guide future research.

In the publications, the topics project management, knowledge management and performance were found to be still poorly related, making it a challenging field for future studies.

A number of organizations were verified to already recognize the relevance of these assets, but have not implemented it in a systemic way, thus finding barriers to associate them with success. This study also has a practical contribution, since it can help project managers to more effectively coordinate the implementation of knowledge management and / or to better understand the benefits and challenges of knowledge management in this context. In addition, the work brings insights that knowledge management is related to project success, helping to motivate practitioners and organizations to make efforts towards knowledge management.

Another contribution of this article is the data analysis method itself, which is structured and, thus, replicable to other themes. However, these methodological choices bring limitations to research. The sample is limited by using a single selected database; also, search strings and inclusion and exclusion criteria for articles may have limited the sample. The inherent subjectivity of the process of analyzing the coding of the literature by the researchers may bias the analysis. Finally, our suggestion is that the discussion between the relationships of the coded themes, particularly regarding the relationship between knowledge management and project management, be explored in field studies, promoting contextualization of the results from case studies and advancing the operationalization of the variables in survey-type confirmatory studies. 


\section{References}

Addis, M. (2016). Tacit and explicit knowledge in construction management. Construction Management and Economics, 34(7-8), 439-445. http://dx.doi.org/10.1080/01446193.2016.1180416.

Ajmal, M., Helo, P., \& Kekäle, T. (2010). Critical factors for knowledge management in project business. Journal of Knowledge Management, 14(1), 156-168. http://dx.doi.org/10.1108/13673271011015633.

Akgün, A. E., Dayan, M., \& Di Benedetto, A. (2008). New product development team intelligence: antecedents and consequences. Information \& Management, 45(4), 221-226. http://dx.doi.org/10.1016/j.im.2008.02.004.

Ali, I., Musawir, A. U., \& Ali, M. (2018). Impact of knowledge sharing and absorptive capacity on project performance: the moderating role of social processes. Journal of Knowledge Management, 22(2), 453-477. http://dx.doi.org/10.1108/JKM-10-2016-0449.

Anbari, F. T., Carayannis, E. G., \& James, R. (2008). Post-project reviews as a key project management competence, Technovation, 28, 633-643. https://doi.org/10.1016/j.technovation.2007.12.001

Andreeva, T., \& Kianto, A. (2012). Does knowledge management really matter? Linking knowledge management practices, competitiveness and economic performance. Journal of Knowledge Management, 16(4), 617-636. http://dx.doi.org/10.1108/13673271211246185.

Borgatti, S. P., Everett, M. G., \& Freeman, L. C. (2002). Ucinet for Windows: Software for social network analysis. Harvard, MA: Analytic Technologies. Recuperado em 14 de setembro de 2018, de https://sites.google.com/site/ucinetsoftware/home

Carvalho, M. M., Patah, L. A., \& Souza Bido, D. (2015). Project management and its effects on project success: cross-country and cross-industry comparisons. International Journal of Project Management, 33(7), 1509-1522. http://dx.doi.org/10.1016/j.jproman.2015.04.004.

Carvalho, M. M., Fleury, A., \& Lopes, A. P. (2013). An overview of the literature on technology roadmapping (TRM): contributions and trends. Technological Forecasting and Social Change, 80(7), 1418-1437. http://dx.doi.org/10.1016/j.techfore.2012.11.008.

Carvalho, M. M., \& Rabechini, R., Jr. (2017). Can project sustainability management impact project success? An empirical study applying a contingent approach. International Journal of Project Management, 35(6), 1120-1132. http://dx.doi.org/10.1016/j.jproman.2017.02.018.

Carvalho, M. M., \& Rabechini, R., Jr. (2015). Fundamentos em gestão de projetos: construindo competências para gerenciar projetos. São Paulo: Atlas

Chandrasekaran, A., \& Linderman, K. (2015). Managing knowledge creation in High-Tech R \& D Projects: A multimethod study. Decision Sciences, 46(2), 267-300.

Choi, B., \& Lee, H. (2003). An empirical investigation of KM styles and their effect on corporate performance. Information \& Management, 40(5), 403-417. http://dx.doi.org/10.1016/S03787206(02)00060-5.

Cohen, J. F., \& Olsen, K. (2015). Expert Systems with Applications Knowledge management capabilities and firm performance: A test of universalistic, contingency and complementarity perspectives. Expert Systems with Applications, 42(3), 1178-1188. http://dx.doi.org/10.1016/j.eswa.2014.09.002.

Collinson, S. (1999). Knowledge management capabilities for steel makers: A British-Japanese corporate alliance for organizational learning. Technology Analysis and Strategic Management, 11(3), 337-358. http://dx.doi.org/10.1080/095373299107393.

Cunha, J. A., Figueiredo, J., Matos, F., \& Thomaz, J. (2014, September). Knowledge Management on PMO's Perspective: A Systematic Review. In Proceedings of the European Conference on Knowledge Management (Vol. 1, p. 233). Santarém, Portugal: Academic Conferences International Limited.

Duffield, S. M., \& Whitty, S. J. (2016). Application of the systemic lessons learned knowledge model for organisational learning through projects. International Journal of Project Management, 34(7), 12801293. http://dx.doi.org/10.1016/j.jproman.2016.07.001.

Franco, E. F., Hirama, K., \& Carvalho, M. M. (2018). Applying system dynamics approach in software and information system projects: A mapping study. Information and Software Technology, 93, 58-73. http://dx.doi.org/10.1016/j.infsof.2017.08.013. 
Grigoriou, K., \& Rothaermel, F. T. (2017). Organizing for knowledge generation: Internal knowledge networks and the contingent effect of external knowledge sourcing. Strategic Management Journal, 38(2), 395-414. http://dx.doi.org/10.1002/smj.2489.

Han, K. H., \& Park, J. W. (2009). Expert Systems with Applications Process-centered knowledge model and enterprise ontology for the development of knowledge management system. Expert Systems with Applications, 36(4), 7441-7447. http://dx.doi.org/10.1016/j.eswa.2008.09.031.

Hanisch, B., Lindner, F., Mueller, A., \& Wald, A. (2009). Knowledge management in project environments. Journal of Knowledge Management, 13(4), 148-160. http://dx.doi.org/10.1108/13673270910971897.

Hong, H. K., Kim, J. S., Kim, T., \& Leem, B. H. (2008). The effect of knowledge on system integration project performance. Industrial Management \& Data Systems, 108(3), 385-404. http://dx.doi.org/10.1108/02635570810858787.

Hynes, M. D., Getzin, S. A., McQuaid, L., Seward, C. M., Miller, N. L., \& Field-Perez, R. R. (1999). Creation of a knowledge-based system to accelerate drug development. Drug Information Journal, 33(2), 641648. http://dx.doi.org/10.1177/009286159903300234.

Landaeta, R. E. (2008). Evaluating benefits and challenges of knowledge transfer across projects. Engineering Management Journal, 20(1), 29-38. http://dx.doi.org/10.1080/10429247.2008.11431753.

Lech, P. (2014). Managing knowledge in IT projects: a framework for enterprise system implementation. Journal of Knowledge Management, 18(3), 551-573. http://dx.doi.org/10.1108/JKM-01-2014-0006.

Lee, J., Lee, H., \& Park, J. (2014). Exploring the impact of empowering leadership on knowledge sharing, absorptive capacity and team performance in IT service. Information Technology \& People, 27(3), 366-386. http://dx.doi.org/10.1108//TP-10-2012-0115.

Lindhard, S., \& Larsen, J. K. (2016). Identifying the key process factors affecting project performance. Engineering, Construction, and Architectural Management, 23(5), 657-673. http://dx.doi.org/10.1108/ECAM-08-2015-0123.

Lindner, F., \& Wald, A. (2011). Success factors of knowledge management in temporary organizations. JPMA, 29(7), 877-888. http://dx.doi.org/10.1016/j.jproman.2010.09.003.

Liu, P. L. (2011). Empirical study on influence of critical success factors on ERP knowledge management on management performance in high-tech industries in Taiwan. Expert Systems with Applications, 38(8), 10696-10704. http://dx.doi.org/10.1016/j.eswa.2011.02.045.

López-Nicolás, C., \& Merono-Cerdán, Á. L. (2011). Strategic knowledge management, innovation and performance. International Journal of Information Management, 31(6), 502-509. http://dx.doi.org/10.1016/j.jijnfomgt.2011.02.003.

McClory, S., Read, M., \& Labib, A. (2017). Conceptualising the lessons-learned process in project management: towards a triple-loop learning framework. International Journal of Project Management, 35(7), 1322-1335. http://dx.doi.org/10.1016/j.jproman.2017.05.006.

Nkuruziza, G., Kasekende, F., Otengei, S. O., Mujabi, S., \& Ntayi, J. M. (2016). An investigation of key predictors of performance of agricultural projects in Sub-Saharan Africa: A case of Uganda. International Journal of Social Economics, 43(7), 676-691. http://dx.doi.org/10.1108/JUSE-09-20140181.

Nonaka, I., \& Takeuchi, H. (1995). The knowledge-creating company: How Japanese companies create the dynamics of innovation. New York: Oxford University Press.

Olayinka, R., Suresh, S., \& Chinyio, E. (2015). Impact of knowledge management on the cost of poor quality. Proceedings of the Institution of Civil Engineers-Management, Procurement and Law, 168(4), 177-188. http://dx.doi.org/10.1680/mpal.1400035.

Oluikpe, P. I. (2015). Knowledge creation and utilization in project teams. Journal of Knowledge Management, 19(2), 351-371. http://dx.doi.org/10.1108/JKM-06-2014-0214.

Oun, T. A., Blackburn, T. D., Olson, B. A., Blessner, P., \& George, T. (2016). An enterprise-wide knowledge management approach to project management. Engineering Management Journal, 28(3), 179-192. http://dx.doi.org/10.1080/10429247.2016.1203715. 
Palacios-Marqués, D., Cortés-Grao, R., \& Carral, C. L. (2013). Outstanding knowledge competences and web 2.0 practices for developing successful e-learning project management. International Journal of Project Management, 31(1), 14-21. http://dx.doi.org/10.1016/j.jproman.2012.08.002.

Park, J., \& Lee, J. (2014). Knowledge sharing in information systems development projects: explicating the role of dependence and trust. JPMA, 32(1), 153-165. http://dx.doi.org/10.1016/j.jproman.2013.02.004.

Parolia, N., Goodman, S., Li, Y., \& Jiang, J. J. (2007). Mediators between coordination and IS project performance. Information \& Management, 44(7), 635-645. http://dx.doi.org/10.1016/j.im.2007.06.003.

Patnayakuni, R., Rai, A., \& Tiwana, A. (2007). Systems development process improvement: A knowledge integration perspective. IEEE Transactions on Engineering Management, 54(2), 286-300. http://dx.doi.org/10.1109/TEM.2007.893997.

Petter, S., \& Vaishnavi, V. (2008). Facilitating experience reuse among software project managers. Information Sciences, 178(7), 1783-1802. http://dx.doi.org/10.1016/j.ins.2007.11.020.

Project Management Institute. (2017). A guide to the project management body of knowledge (PMBOK® guide). (6th ed.). Newtown Square: PMI.

Reich, B. H., Gemino, A., \& Sauer, C. (2014). How knowledge management impacts performance in projects: an empirical study. International Journal of Project Management, 32(4), 590-602. http://dx.doi.org/10.1016/j.jproman.2013.09.004.

Reich, B. H., Gemino, A., \& Sauer, C. (2012). Knowledge management and project-based knowledge in it projects: A model and preliminary empirical results. International Journal of Project Management, 30(6), 663-674. http://dx.doi.org/10.1016/j.jpproman.2011.12.003.

Sáenz, J., Aramburu, N., \& Blanco, C. E. (2012). Knowledge sharing and innovation in Spanish and Colombian high-tech firms. Journal of Knowledge Management, 16(6), 919-933. http://dx.doi.org/10.1108/13673271211276191.

Savolainen, P., \& Ahonen, J. J. (2015). Knowledge lost: Challenges in changing project manager between sales and implementation in software projects. JPMA, 33(1), 92-102. http://dx.doi.org/10.1016/j.jproman.2014.04.003.

Sharif, S. A., \& Kayis, B. (2007). DSM as a knowledge capture tool in CODE environment. Journal of Intelligent Manufacturing, 18(4), 497-504. http://dx.doi.org/10.1007/s10845-007-0058-0.

Spalek, S. (2015). Establishing a conceptual model for assessing project management maturity in industrial companies. International Journal of Industrial Engineering, 22(2)

Storey, C., \& Hull, F. M. (2010). Service development success: A contingent approach by knowledge strategy. Journal of Service Management, 21(2), 140-161. http://dx.doi.org/10.1108/09564231011039268.

Suikki, R., Tromstedt, R., \& Haapasalo, H. (2006). Project management competence development framework in turbulent business environment. Technovation, 26(5-6), 723-738. http://dx.doi.org/10.1016/j.technovation.2004.11.003.

Suresh, S., Olayinka, R., Chinyio, E., \& Renukappa, S. (2016). Impact of knowledge management on construction projects. Proceedings of the Institution of Civil Engineers-Management, Procurement and Law, 170(1): 27-48.

Todorović, M. L., Petrović, D. Č., Mihić, M. M., Obradović, V. L., \& Bushuyev, S. D. (2015). Project success analysis framework: A knowledge-based approach in project management. International Journal of Project Management, 33(4), 772-783. http://dx.doi.org/10.1016/j.jproman.2014.10.009.

Xu, P., \& Ramesh, B. (2008). Impact of knowledge support on the performance of software process tailoring. Journal of Management Information Systems, 25(3), 277-314. http://dx.doi.org/10.2753/MIS0742-1222250308.

Yap, J. B. H., Abdul-rahman, H., \& Chen, W. (2017). Collaborative model: managing design changes with reusable project experiences through project learning and effective communication. International Journal of Project Management, 35(7), 1253-1271. http://dx.doi.org/10.1016/j.jproman.2017.04.010. 
Zangiski, M. A. D. S. G., de Lima, E. P., \& da Costa, S. E. G. (2013). Organizational competence building and development: contributions to operations management. International Journal of Production Economics, 144(1), 76-89. http://dx.doi.org/10.1016/j.jpe.2013.01.021.

Zhang, J., Li, H., \& Wang, S. H. (2017). Analysis and Potential application of the maturity of growth management in the developing construction industry of a Province of China: A case study. Sustainability, 9(1), 1-36. https://doi.org/10.3390/su9010143. 
Appendix A - Content Analysis Summary

\begin{tabular}{|c|c|c|c|c|c|c|c|c|c|c|c|c|c|c|c|c|c|c|c|c|c|c|c|c|c|c|c|c|}
\hline \multirow{2}{*}{$\begin{array}{c}\text { Code } \\
\text { Reference }\end{array}$} & \multicolumn{3}{|c|}{$\mathrm{C} 1$} & \multicolumn{3}{|c|}{ C2 } & \multicolumn{3}{|c|}{ C3 } & \multicolumn{4}{|c|}{ C4 } & \multicolumn{2}{|c|}{ C5 } & \multicolumn{3}{|c|}{ C6 } & \multicolumn{4}{|c|}{ C7 } & \multicolumn{6}{|c|}{ C8 } \\
\hline & TE1 TE2 $T$ & TE3 TE4 TE5 & TE6 TE7 TE8 & A1 & A2 & A3 & NA1 & NA2 & NA3 & S1 & S2 & s3 & S4 & C1 & C2 & IE2 & IE2 & IE3 IE4 & IT1 & IT2 & IT3 I7 & IT4 & DDP1 & DDP2 & DDP3 & DDP4 & DDP5 & DDP6 DDP7 \\
\hline $\begin{array}{c}\text { Zhang \& Wang } \\
\text { (2017) }\end{array}$ & & & 1 & & 1 & & & & 1 & & & & 1 & 1 & & & & & & & 1 & & & & & & 1 & 1 \\
\hline Suresh et al. (2017) & & 1 & & & & 1 & & 1 & 1 & & & & 1 & 1 & 1 & 1 & & & & & & 1 & & 1 & & & & \\
\hline $\begin{array}{l}\text { McClory et al. } \\
(2017)\end{array}$ & & 1 & & 1 & & & 1 & & 1 & & & & 1 & 1 & 1 & & & 1 & 1 & & & & & 1 & & & 1 & \\
\hline Oun et al. (2016) & & 1 & & & 1 & & & 1 & & & & & 1 & 1 & 1 & & & 1 & & & 1 & & & 1 & & & & \\
\hline $\begin{array}{c}\text { Nkuruziza et al. } \\
\text { (2016) }\end{array}$ & & 1 & & & 1 & & & 1 & & & & & 1 & 1 & 1 & & & & & & 1 & & & 1 & & & & \\
\hline Addis (2016) & 1 & & & 1 & & & & 1 & & & & & 1 & 1 & 1 & & & 1 & 1 & & & & & 1 & & & & \\
\hline Spalek (2015) & & 1 & & & 1 & & & 1 & & 1 & & & & & 1 & & & 1 & & & & & & 1 & & & & \\
\hline $\begin{array}{l}\text { Olayinka et al. } \\
\text { (2015) }\end{array}$ & & 1 & & 1 & & & 1 & 1 & 1 & & & & 1 & 1 & 1 & & 1 & 1 & 1 & 1 & & 1 & 1 & & & 1 & & \\
\hline Oluikpe (2015) & & 1 & & & 1 & & & 1 & 1 & & & & 1 & 1 & 1 & 1 & & & & & 1 & & 1 & 1 & & & & \\
\hline $\begin{array}{l}\text { Chandrasekaran \& } \\
\text { Linderman (2015) }\end{array}$ & & 1 & 1 & & & 1 & & 1 & & & 1 & & & 1 & 1 & & & 1 & 1 & & & & 1 & 1 & & & & \\
\hline $\begin{array}{c}\text { Todorovic et al. } \\
\text { (2015) }\end{array}$ & & 1 & & & 1 & & & 1 & & 1 & 1 & & 1 & & 1 & 1 & & 1 & & & & & & 1 & & & & \\
\hline $\begin{array}{c}\text { Savolainen \& } \\
\text { Ahonen (2015) }\end{array}$ & & & 1 & 1 & & & & 1 & 1 & & 1 & & & 1 & 1 & & & 1 & 1 & & & & 1 & 1 & & & & \\
\hline Lee et al. (2014) & & 1 & & & 1 & & 1 & & & & 1 & & & 1 & & & & & & & 1 & & & 1 & 1 & & & \\
\hline Reich et al. (2014) & & 1 & & & 1 & & & 1 & & & 1 & & & 1 & & & & & 1 & & 1 & & & 1 & & 1 & & \\
\hline Park \& Lee (2014) & & 1 & & & 1 & & 1 & 1 & & & 1 & & & 1 & & & & & & & 1 & & & 1 & 1 & & & \\
\hline Lech (2014) & & & 1 & 1 & & & & 1 & & & 1 & & & 1 & & & & & 1 & & & & 1 & & & & & \\
\hline $\begin{array}{l}\text { Zangiski et al. } \\
\text { (2013) }\end{array}$ & 1 & & & 1 & & & & & 1 & 1 & & & & 1 & & & & & & & 1 & & 1 & & & 1 & & \\
\hline $\begin{array}{l}\text { Palacios- } \\
\text { Marques et al. } \\
\text { (2013) }\end{array}$ & & 1 & & 1 & & & 1 & & & & 1 & & & 1 & & & & & & & & 1 & 1 & & 1 & & & \\
\hline Reich et al. (2012) & & 1 & & & 1 & & & 1 & & & 1 & & & 1 & & & & & & & 1 & & 1 & & & 1 & & \\
\hline Sáenz et al. (2012) & & 1 & & & 1 & & & 1 & 1 & & 1 & & & 1 & & & & & 1 & & 1 & & 1 & & & 1 & & \\
\hline
\end{tabular}




\section{Appendix A - Continued...}

\begin{tabular}{|c|c|c|c|c|c|c|c|c|c|c|c|c|c|c|c|c|c|c|c|c|c|c|c|c|c|c|c|c|}
\hline \multirow{2}{*}{$\begin{array}{c}\text { Code } \\
\text { Reference }\end{array}$} & \multicolumn{3}{|c|}{ C1 } & \multicolumn{3}{|c|}{ C2 } & \multicolumn{3}{|c|}{ C3 } & \multicolumn{4}{|c|}{ C4 } & \multicolumn{2}{|c|}{ C5 } & \multicolumn{4}{|c|}{ C6 } & \multicolumn{4}{|c|}{ C7 } & \multicolumn{5}{|c|}{ C8 } \\
\hline & TE1 & 1 TE2 TE3 TE4 TE5 & TE6 TE7 TE8 & A1 & A2 & A3 & NA1 & NA2 & NA3 & s1 & S2 & S3 & S4 & C1 & $\mathrm{C2}$ & IE2 & IE2 & IE3 & $\overline{\text { IE4 }}$ & IT1 & IT2 & IT3 & IT4 & DDP1 & DDP2 & DDP3 & DDP4 & DDP5 DDP6 DDP7 \\
\hline Liu (2011) & & 1 & & & 1 & & & & 1 & & 1 & & & & 1 & 1 & & 1 & & & & & & & 1 & & 1 & \\
\hline $\begin{array}{l}\text { Lindner \& Wald } \\
\qquad(2011)\end{array}$ & & 1 & & & 1 & & & & 1 & 1 & 1 & & 1 & 1 & 1 & & & 1 & & & & 1 & & & 1 & & 1 & \\
\hline Ajmal et al. (2010) & & 1 & & 1 & & & 1 & 1 & & & & & 1 & & 1 & & & & 1 & & & & & & 1 & 1 & & \\
\hline Han \& Park (2009) & & 1 & & 1 & & & & & 1 & & & & 1 & 1 & 1 & 1 & & & & 1 & & & & 1 & & & 1 & \\
\hline $\begin{array}{l}\text { Hanisch et al. } \\
\text { (2009) }\end{array}$ & & 1 & & 1 & & & & 1 & 1 & 1 & 1 & & 1 & 1 & & & & & & 1 & & & & & & & 1 & \\
\hline Landaeta (2008) & & 1 & & & 1 & & & 1 & 1 & 1 & 1 & & & 1 & 1 & 1 & & & & 1 & & & & & 1 & & & \\
\hline $\begin{array}{l}\text { Xu \& Ramesh } \\
\text { (2008) }\end{array}$ & & 1 & & & 1 & & & & 1 & & 1 & & & 1 & 1 & 1 & 1 & & & 1 & & & 1 & 1 & & & & \\
\hline Akgun et al. (2008) & & 1 & & & 1 & & & 1 & & & & & 1 & 1 & & & & & & 1 & & & & 1 & & 1 & & \\
\hline Anbari et al. (2008) & & 1 & & 1 & & & & 1 & & & & & 1 & & 1 & 1 & 1 & 1 & 1 & & & & & & 1 & 1 & & \\
\hline Hong et al. (2008) & 1 & & & & 1 & & & 1 & & & & & 1 & 1 & 1 & 1 & & & & 1 & & & & & & 1 & & 1 \\
\hline $\begin{array}{l}\text { Petter \& Vaishnavi } \\
\text { (2008) }\end{array}$ & 1 & & & 1 & & & & & 1 & & & & 1 & 1 & 1 & & & 1 & 1 & 1 & & 1 & & 1 & & & & \\
\hline $\begin{array}{l}\text { Sharif \& Kayis } \\
\text { (2007) }\end{array}$ & 1 & & 1 & & & 1 & & & 1 & 1 & & & & & 1 & & & 1 & 1 & & & & & 1 & & & & \\
\hline Parolia et al. (2007) & & 1 & & & 1 & & & 1 & & & & & 1 & & 1 & & 1 & & & & & & & & 1 & 1 & & \\
\hline $\begin{array}{l}\text { Patnayakuni et al. } \\
\text { (2007) }\end{array}$ & & 1 & & & 1 & & & 1 & & & 1 & & & & 1 & & & 1 & & & & & & 1 & & & & \\
\hline Suikki et al. (2006) & & 1 & & 1 & & & & 1 & 1 & & & & & 1 & & & & & & 1 & & & 1 & & 1 & & & 1 \\
\hline Hynes et al. (1999) & & & 1 & & & & & 1 & & & & & 1 & & 1 & & & & 1 & & & & & 1 & 1 & & & \\
\hline Collinson (1999) & & & 1 & & 1 & & & & 1 & 1 & & & & 1 & 1 & & & 1 & 1 & 1 & 1 & 1 & & 1 & & 1 & 1 & \\
\hline
\end{tabular}


Appendix B - Cross-analysis according to the coding scheme

\begin{tabular}{|c|c|c|c|c|c|c|c|c|c|c|c|c|c|c|c|c|c|}
\hline & C1 & C2 & IE2 & IE2 & IE3 & IE4 & IT1 & IT2 & IT3 & IT4 & DDP1 & DDP2 & DDP3 & DDP4 & DDP5 & DDP6 & DDP7 \\
\hline C1 & 28 & 16 & 6 & 2 & 9 & 2 & 17 & 2 & 13 & 5 & 14 & 14 & 6 & 9 & 4 & 0 & 1 \\
\hline $\mathrm{C} 2$ & 16 & 25 & 9 & 4 & 15 & 6 & 11 & 2 & 6 & 3 & 11 & 17 & 5 & 5 & 2 & 0 & 0 \\
\hline IE2 & 6 & 9 & 9 & 2 & 3 & 1 & 4 & 0 & 1 & 2 & 3 & 6 & 2 & 2 & 1 & 0 & 0 \\
\hline IE2 & 2 & 4 & 2 & 4 & 2 & 1 & 2 & 1 & 0 & 2 & 2 & 2 & 2 & 1 & 0 & 0 & 0 \\
\hline IE3 & 9 & 15 & 3 & 2 & 15 & 4 & 7 & 2 & 4 & 1 & 7 & 10 & 2 & 4 & 1 & 0 & 0 \\
\hline IE4 & 2 & 6 & 1 & 1 & 4 & 6 & 2 & 1 & 2 & 0 & 4 & 3 & 3 & 1 & 0 & 0 & 0 \\
\hline IT1 & 17 & 11 & 4 & 2 & 7 & 2 & 17 & 2 & 4 & 3 & 10 & 7 & 3 & 6 & 3 & 0 & 0 \\
\hline IT2 & 2 & 2 & 0 & 1 & 2 & 1 & 2 & 2 & 1 & 1 & 2 & 0 & 1 & 2 & 0 & 0 & 0 \\
\hline IT3 & 13 & 6 & 1 & 0 & 4 & 2 & 4 & 1 & 13 & 0 & 6 & 7 & 3 & 6 & 1 & 0 & 1 \\
\hline IT4 & 5 & 3 & 2 & 2 & 1 & 0 & 3 & 1 & 0 & 5 & 3 & 2 & 1 & 1 & 1 & 0 & 0 \\
\hline DDP1 & 14 & 11 & 3 & 2 & 7 & 4 & 10 & 2 & 6 & 3 & 17 & 4 & 3 & 6 & 0 & 0 & 0 \\
\hline DDP2 & 14 & 17 & 6 & 2 & 10 & 3 & 7 & 0 & 7 & 2 & 4 & 21 & 5 & 3 & 2 & 0 & 0 \\
\hline DDP3 & 6 & 5 & 2 & 2 & 2 & 3 & 3 & 1 & 3 & 1 & 3 & 5 & 9 & 1 & 1 & 0 & 0 \\
\hline DDP4 & 9 & 5 & 2 & 1 & 4 & 1 & 6 & 2 & 6 & 1 & 6 & 3 & 1 & 10 & 0 & 0 & 0 \\
\hline DDP5 & 4 & 2 & 1 & 0 & 1 & 0 & 3 & 0 & 1 & 1 & 0 & 2 & 1 & 0 & 4 & 0 & 1 \\
\hline DDP6 & 0 & 0 & 0 & 0 & 0 & 0 & 0 & 0 & 0 & 0 & 0 & 0 & 0 & 0 & 0 & 0 & 0 \\
\hline DDP7 & 1 & 0 & 0 & 0 & 0 & 0 & 0 & 0 & 1 & 0 & 0 & 0 & 0 & 0 & 1 & 0 & 1 \\
\hline
\end{tabular}

